\title{
MENINGKATKAN KETERAMPILAN MENULIS KARANGAN PESERTA DIDIK KELAS IV SD NEGERI 007 PANGKALAN BARU KECAMATAN SIAK HULU KABUPATEN KAMPAR MELALUI MODEL PEMBELAJARAN KOOPERATIF EXAMPLES NON EXAMPLES
}

\author{
Hasnidar $^{1}$ \\ Universitas Pahlawan Tuanku Tambusaii ${ }^{1}$ \\ e-mail : hasnidar@gmail.com
}

\begin{abstract}
Abstrak
Penelitian ini dilatarbelakangi oleh kurangnya keterampilan menulis karangan siswa kelas IV SD Negeri 007 Pangkalan Baru Kecamatan Siak Hulu Kabupaten Kampar. Penelitian ini bertujuan untuk mengetahui apakah keterampilan menulis karangan sesuai EYD pada peserta didik kelas IV SD Negeri 007 Pangkalan Baru Kecamatan Siak Hulu Kabupaten Kampar dapat ditingkatkan melalui model pembelajaran kooperatif Examples non Examples. Penelitian ini merupakan penelitian tindakan kelas (PTK). Subjek penelitian ini adalah semua peserta didik kelas IV SD Negeri 007 Pangkalan Baru Kecamatan Siak Hulu Kabupaten Kampar dengan jumlah 27 orang, yang terdiri dari 13 orang laki-laki dan 14 orang perempuan. Berdasarkan hasil penelitian, bahwa keterampilan menulis karangan sesuai EYD pada peserta didik kelas IV SD Negeri 007 Pangkalan Baru Kecamatan Siak Hulu Kabupaten Kampar dapat ditingkatkan melalui model pembelajaran kooperatif Examples non Examples. Hal ini diketahui dari keterampilan menulis karangan peserta didik pada pra siklus tercapai pada rata-rata 72,67. Pada siklus pertama atau setelah diterapkannya model pembelajaran kooperatif Examples non Examples, meningkat menjadi 73,15. Pada siklus kedua keterampilan menulis karangan peserta didik kelas IV SD Negeri 007 Pangkalan Baru Kecamatan Siak Hulu Kabupaten Kampar meningkat menjadi 81,48 dengan ketuntasan 100\% peserta didik.

Kata Kunci : Keterampilan menulis karangan, dan model pembelajaran kooperatif Examples non Examples
\end{abstract}

@Edukasi: Jurnal Ilmu Pendidikan FIP UPTT 2019

$\triangle$ Corresponding author :

Address : Pekanbaru

ISSN $\mathrm{xxxx}-\mathrm{xxxx}$ (Media Cetak)

Email : hasnidar@gmail.com

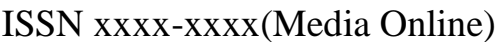

Phone :- 


\section{PENDAHULUAN}

Kita ketahui bahwa keterampilan berbahasa mencakup empat aspek, yaitu keterampilan membaca, keterampilan menyimak, keterampilan berbicara, dan keterampilan menulis. Salah satu aspek dari keterampilan berbahasa adalah menulis. Keterampilan menulis yang dimiliki peserta didik akan sangat membantu peserta didik dalam menyampaikan pesan atau sebagai sarana untuk mengungkapkan idenya, gagasan, atau pikiran secara lisan. Sebagaimana tercantum dalam kurikulum KTSP yang disusun oleh Badan Standar Nasional Pendidikan (BSNP) bahwa keterampilan menulis untuk peserta didik kelas IV Sekolah Dasar meliputi kompetensi dasar: (1) melengkapi percakapan yang belum selesai dengan memperhatikan penggunaan Ejaan Yang Disempurnakan (huruf besar, tanda titik, tanda koma); (2) menulis karangan dengan memperhatikan penggunaan EYD (huruf besar, tanda titik, tanda koma; dan (3) menulis surat untuk teman sebaya tentang pengalaman atau citacita dengan bahasa yang baik dan benar dan memperhatikan penggunaan Ejaan Yang Disempurnakan (huruf besar, tanda titik, tanda koma).

Melalui hasil pengamatan penulis sebagai guru di Sekolah Dasar Negeri 007 Pangkalan Baru Kecamatan Siak Hulu Kabupaten Kampar, bahwa ditemui fenomena khususnya pada pelajaran Bahasa Indonesia, antara lain adalah (1) rendahnya keterampilan peserta didik kelas IV 007 Pangkalan Baru Kecamatan Siak Hulu Kabupaten Kampar dalam menulis karangan dengan memperhatikan tanda titik, tanda koma dan huruf besar, dimana dari 27 orang jumlah peserta didik hanya ada 4 orang yang mencapai nilai KKM yang ditetapkan sekolah (minimal nilai 70); (2) kurangnya keingintahuan peserta didik terhadap materi pelajaran yang disampaikan oleh guru; dan (3) peserta didik kurang memiliki keberanian untuk mengemukakan pendapat atau ide-ide dalam pelaksanaan pembelajaran di kelas.

Berdasarkan beberapa fenomena tersebut, mengindikasikan kurangnya keterampilan peserta didik dalam menulis karangan. Keadaan tersebut, menurut analisa penulis dipengaruhi oleh metode pembelajaran yang digunakan guru selama ini dalam menyampaikan materi menulis.

Selama ini guru sudah melakukan beberapa usaha sebagai contoh menerapkan model pembelajaran latihan secara berulang-ulang. Tetapi tetap saja keterampilan menulis tidak tercapai pada $85 \%$ peserta didik mencapai Kriteria Ketuntasan
Minimal (KKM) 70 yang ditetapkan. Oleh sebab itu, diperlukan suatu pembelajaran yang menyenangkan dan mudah, mudah dalam hal menerapkan dan mudah diikuti peserta didik dalam belajar, yang paling penting adalah mudah dipahami peserta didik.

Salah satu pembelajaran yang dapat memudahkan peserta didik dalam memahami materi pelajaran adalah model pembelajaran kooperatif Examples non Examples. Pembelajaran kooperatif adalah pembelajaran yang dilakukan secara berkelompok. Sedangkan Examples non Examples merupakan pendekatan dengan media gambar. Jadi pembelajaran kooperatif Examples non Examples adalah proses belajar secara berkelompok dengan media gambar. Melalui kegiatan kelompok dan media gambar peserta didik diberi kemudahan dalam menulis karangan.

Berdasarkan uraian tersebut, penulis tertarik melakukan penelitian tindakan sebagai upaya perbaikan dan peningkatan pembelajaran dengan judul "Meningkatkan Keterampilan Menulis Karangan Peserta didik Kelas IV SD Negeri 007 Pangkalan Baru Kecamatan Siak Hulu Kabupaten Kampar Melalui Model Pembelajaran Kooperatif Examples non Examples"

\section{METODE PENELITIAN}

Desain penelitian yang digunakan adalah desain penelitian tindakan kelas (PTK). Menurut Arikunto (2006:76) penelitian tindakan kelas adalah penelitian yang dilakukan di kelas dengan tujuan memperbaiki atau meningkatkan mutu pembelajaran

Wardani (2010:1.19) mengatakan bahwa penelitian tindakan kelas (PTK) mempunyai manfaat cukup besar, baik bagi guru, pembelajaran, maupun bagi sekolah. Manfaat tersebut adalah (1) PTK dapat dimanfaatkan oleh guru untuk memperbaiki pembelajaran yang dikelolanya karena memang sasaran akhir PTK adalah perbaikan pembelajaran; (2) dengan melakukan PTK guru dapat berkembang secara profesioanl karena dapat menunjukkan bahwa ia mampu menilai dan memperbaiki pembelajaran yang dikelolanya; (3) PTK membuat guru lebih percaya diri, sebab PTK mampu membuat guru berkembang sebagai pekerja professional, maka sebagai konsekuensinya PTK juga mampu membuat guru lebih percaya diri; dan (4) melalui PTK, guru mendapat kesempatan untuk berperan aktif mengembangkan pengetahuan dan keterampilan sendiri. 


\section{HASIL PENELITIAN DAN PEMBAHASAN}

Rata-rata dan ketuntasan yang diperoleh peserta didik dari sebelum penerapan model pembelajaran kooperatif examples non examples dan sesudah penerapan model pembelajaran kooperatif examples non examples mengalami peningkatan. Lebih jelasnya dapat dilihat pada table 4.8 berikut ini.

\section{Tabel 1}

Rata-rata Keterampilan Menulis Karangan dari Pra Siklus hingga Siklus II

\begin{tabular}{|c|c|c|c|c|}
\hline $\begin{array}{c}\text { N } \\
\text { o }\end{array}$ & $\begin{array}{c}\text { Siklu } \\
\text { s }\end{array}$ & $\begin{array}{c}\text { Rata- } \\
\text { rata }\end{array}$ & $\begin{array}{c}\text { Pesert } \\
\text { a didik } \\
\text { Tuntas }\end{array}$ & $\begin{array}{c}\text { Persentas } \\
\text { e }\end{array}$ \\
\hline 1 & $\begin{array}{c}\text { Pra } \\
\text { siklus }\end{array}$ & $\begin{array}{c}72,6 \\
7\end{array}$ & 18 & 66,67 \\
\hline 2 & $\begin{array}{c}\text { Siklu } \\
\text { s I }\end{array}$ & $\begin{array}{c}73,1 \\
5\end{array}$ & 19 & 70,37 \\
\hline 3 & $\begin{array}{c}\text { Siklu } \\
\text { s II }\end{array}$ & $\begin{array}{c}81,4 \\
8\end{array}$ & 27 & 100 \\
\hline
\end{tabular}

Sumber: Hasil Olahan Data Penelitian, 2014

Sebelum diterapkannya model pembelajaran kooperatif examples non examples, keterampilan peserta didik tercapai pada rata-rata nilai 72,67 dengan peserta didik yang tuntas 18 orang $(66,67 \%)$, meningkat menjadi 73,15 dengan ketuntasan 19 peserta didik $(70,37 \%)$ pada siklus pertam atau setelah penerapan model pembelajaran kooperatif examples non examples, pada siklus kedua keterampilan menulis peserta didik kelas kelas IV SD Negeri 007 Pangkalan Baru Kecamatan Siak Hulu Kabupaten Kampar meningkatkan menjadi 81,48 dengan 27 peserta didik $(100 \%)$ yang tuntas.

Aktivitas guru pada siklus pertama berkategori baik, walaupun demikian aktivitas guru siklus pertama belum optimal. Hal ini diketahui dari rata-rata aktivitas guru pada siklus pertam hingga siklus kedua pada table berikut ini.

Tabel 2

Aktivitas Guru Siklus I dan Siklus II

\begin{tabular}{|c|c|c|c|}
\hline No & Siklus & $\begin{array}{c}\text { Rata- } \\
\text { rata }\end{array}$ & Keterangan \\
\hline 1 & Siklus I & 64,29 & Baik \\
\hline 2 & Siklus II & 82,14 & Sangat Baik \\
\hline
\end{tabular}

Sumber: Hasil Olahan Data Penelitian, 2014
Diketahui dari table 4.9 bahwa aktivitas guru dalam menerapkan model pembelajaran kooperatif examples non examples berkategori baik dengan rata-rata penilaian 64,29. Setelah diperbaiki pada siklus kedua, aktivitas guru meningkat menjadi 82,14 atau dengan kategori penilaian sangat baik.

Peningkatan aktivitas guru diikuti oleh aktivitas peserta didik dalam mengikuti pembelajaran. Hasil rekapitulasi aktivitas peserta didik selama mengikuti model pembelajaran kooperatif examples non examples dapat dilihat pada tabel berikut.

Tabel 3

Aktivitas Peserta Didik Siklus I dan Siklus I

\begin{tabular}{|l|l|l|r|}
\hline No & Siklus & Rata-rata & $\begin{array}{c}\text { Ketera } \\
\text { ngan }\end{array}$ \\
\hline & Siklus I & 62,70 & Baik \\
\hline & Siklus II & 77,91 & Baik \\
\hline
\end{tabular}

Sumber: Hasil Olahan Data Penelitian, 2014

Berdasarkan tabel 4.10, aktivitas peserta didik kelas IV SD Negeri 007 Pangkalan Baru Kecamatan Siak Hulu Kabupaten Kampar dalam mengikuti model pembelajaran kooperatif examples non examples adalah baik. Peningkatan terjadi pada rata-rata penilaian aktivitas, pada siklus pertama diperoleh rata-rata 62,70 meningkat menjadi 77,91 pada siklus kedua.

Berdasarkan hasil tersebut, bahwa keberhasilan guru dalam menerapkan model pembelajaran kooperatif examples non examples dapat meningkatkan aktivitas dan keterampilan menulis karangan peserta didik kelas IV SD Negeri 007 Pangkalan Baru Kecamatan Siak Hulu Kabupaten Kampar.

\section{KESIMPULAN}

Berdasarkan hasil penelitian dan rumusan masalah penelitian ini, maka dapat disimpulkan bahwa keterampilan menulis karangan sesuai EYD pada peserta didik kelas IV SD Negeri 007 Pangkalan Baru Kecamatan Siak Hulu Kabupaten Kampar dapat ditingkatkan melalui model pembelajaran kooperatif Examples non Examples. Hal ini diketahui dari keterampilan menulis karangan peserta didik pada pra siklus tercapai pada rata-rata 72,67. Pada siklus pertama atau setelah diterapkannya model pembelajaran kooperatif Examples non Examples, meningkat 
33 Meningkatkan keterampilan menulis karangan peserta didik kelas IV SDN 007 Pangkalan Baru Melalui Model Pembelajaran Kooperatif Example non Examples- Hasnidar

menjadi 73,15. Pada siklus kedua keterampilan menulis karangan peserta didik kelas IV SD Negeri 007 Pangkalan Baru Kecamatan Siak Hulu Kabupaten Kampar meningkat menjadi 81,48 dengan ketuntasan $100 \%$ peserta didik

\section{DAFTAR PUSTAKA}

Arikunto. 2006. Penelitian Tindakan Kelas (PTK). Jakarta: Bumi Aksara.

2008. Penelitian Tindakan Kelas (PTK) Edisi Revisi. Jakarta: Bumi Aksara.

Depdikbud. 2002. Kamus Besar Bahasa Indonesia. Jakarta: Balai Pustaka.

I.G.A.K. Wardani. 2010. Penelitian Tindakan Kelas. Jakarta: UT.

Isnaini. 2006. Modul Menulis. Pekanbaru: Cendikia Insani.

KTSP. 2007. Panduan Lengkap KTSP. Yokyakarta: Pustaka Yudhistira

Kunandar. 2007. Guru Profesional Implementasi Kurikulum Tingkat Satuan Pendidikan (KTSP) dan Persiapan Menghadapi Sertifikasi Guru. Jakarta: PT. Raja Grafindo Persada.

Lie. 2007. Cooperative Learning. Jakarta: Grasindo.

Santosa. 2005. Materi dan Pembelajaran Bahasa Indonesia SD. Jakarta: UT.

Shanty. 2006. Kemahiran Menulis. Pekanbaru: Unri Press.

Slamet. 2008. Dasar-dasar Pembelajaran Bahasa dan Sastra Indonesia di Sekolah Dasar. Surakarta: UNS Press.

Slavin. 2008. Cooperative Learning (Teori, Riset, dan Praktik). Bandung: Nusa Media.

Sugiyanto. 2010. Model-model Pembelajaran Inovatif. Surakarta: Yuma Pustaka.

Suprijono, Agus. 2009. Cooperative Learning Teori \& Aplikasi Paikem. Yogyakarta: Pustaka Pelajar.
Syah. 1996. Psikolgi Belajar. Jakarta: Rajawali Pers.

Syahrilfudin. 2011. Metodologi Penelitian. Unri Press.

Tarigan. 2007. Kemampuan Menulis. Bandung: Angkasa. 